J. Amer. Soc. Hort. Sci. 117(6):955-960. 1992.

\title{
Freezing Behavior of Prunus, Subgenus Padus, Flower Buds
}

\author{
Sorkel A. Kader ${ }^{1}$ and Edward L. Proebsting ${ }^{2}$ \\ Irrigated Agriculture Research and Extension Center, Prosser, WA 99350-9687
}

Additional index words. black cherry (Prunus serotina), choke cherry (Prunus virginiana), differential thermal analysis, European bird cherry (Prunus padus), supercooling

\begin{abstract}
Flower buds of Prunus serotina Ehrh. produced high temperature exotherms (HTEs) and low temperature exotherms (LTEs). Supercooling in P. serotina occurred during full dormancy in December and early January but disappeared thereafter, whereas no supercooling was observed in $P$. padus $L$. or $P$. virginiana L. Both intact and detached Inflorescences of $P$. serotina supercooled and froze as a unit and not as individual florets. Exotherms in dehydrated parts occurred at lower temperatures than in hydrated parts. Dormant buds of $P$. serotina lost the detectable exotherms when kept at $-7 \mathrm{C}$ for 2 days, while buds stored at 3C exhibited LTEs between $\mathbf{- 2 0}$ and $-26 \mathrm{C}$. Dormant Morescences of $P$. serotina were filled with elongated procambium and pith cells. In contrast, $P$. padus and $P$. virginiana had differentiated xylem vessel elements (XVE) the entire length of the inflorescence and did not supercool. Bud scales and bud axis of $P$. serotina were the flower parts where water apparently migrated during storage at 3 and $-7 \mathrm{C}$. This was not observed for $P$. padus and $P$. virginiana flower buds. The rate of water migration from the inflorescences to bud scales and axis probably plays a role in the freezing behavior of $P$. serotina.
\end{abstract}

Native Prunus species are widely distributed in North America. $P$. virginiana is distributed in the Boreal forest and other northern latitudes, while $P$. padus, P. maackii Rupr., and $P$. serotina are found in more southern latitudes (Rajashekar and Burke, 1978). Flower buds of many Prunus species avoid freezing by supercooling, thereby avoiding bud injury (Quamme, 1974). However, Prunus taxa with racemose inflorescences usually do not supercool (Rajashekar and Burke, 1978). Prunus serotina is a member of the subgenus Padus, which also includes $P$. padus, $P$. virginiana, and $P$. pensylvanica (Rehder, 1950). This subgenus is characterized by flower buds borne laterally on spurs with a large racemose inflorescence that freeze without deep supercooling (Ashworth, 1984). According to Rajashekar and Burke (1978) and Burke and Stushnoff (1979), the twigs and flower buds of all of the above species, except $P$. serotina, froze without supercooling. Only one flower bud of $P$. serotina did not supercool, while the twigs supercooled to -38C (Rajashekar and Burke, 1978).

Water in the flower bud primordium can supercool if it is isolated from ice crystals or other ice nucleators. Buds that supercool have physical features that prevent ice propagation from the bud scales and bud axis into the bud primordium. The presence or absence of xylem vessel elements is apparently the main factor that determines whether supercooling in Prunus species can occur. Supercooling can occur in dormant flower bud primordia if xylem vessels do not form a continuous conduit between the dormant primordium and bud axis (Ashworth, 1984).

Anatomical observations of several members of the subgenus Padus showed that the racemose inflorescence has large pith cells with large intercellular spaces (Ashworth, 1984). Xylem vessels in $P$. padus and $P$. virginiana were found to extend the length of the raceme and into the pedicels of individual florets

\footnotetext{
Received for publication 10 Mar. 1992. Accepted for publication 13 July 1992. Scientific Paper no. 92-06, Project 0215, Washington State College of Agriculture Research Center. This research was supported in part by grant from the Washington Tree Fruit Research Commission. We wish to thank Bill Howell for providing the plant materials. The cost of publishing this paper was defrayed in part by the payment of page charges. Under postal regulations, this paper therefore must be hereby marked advertisement solely to indicate this fact.
}

'Research Associate. To whom reprint requests should be addressed. ${ }^{2}$ Horticulturist.
(Ashworth, 1984). Supercooling is prevented in such species by the propagation of ice through xylem and pith into the inflorescence. However, the fact that $P$. emarginata Hook is another species with eight to 10 florets born on short racemose (Rehder, 1950) that deep supercooled during winter (Kadir and Proebsting, unpublished) prompted us to study the hypothesis that not all taxa with racemose flowers freeze without supercooling. The objectives of this study were to further study the freezing behavior and the anatomical characteristics of $P$. serotina flower buds and compare them with those of $P$. padus and $P$. virginiana.

\section{Materials and Methods}

Plant materials. Shoots were collected weekly during early December to mid-March of 1989-90 and 1990-91 from trees of $P$. padus, $P$. serotina, and $P$. virginiana in the Interregional Repository of Virus Free Fruit Trees (IR-2) collection of virus tested fruit trees at the Washington State Univ., Irrigated Agriculture Research and Extension Center, Prosser, Wash. Shoots were immediately placed into plastic bags, on ice, and freeze tested within an hour, unless otherwise stated.

Differential thermal analysis (DTA). About 10 to 15 flower buds of $P$. serotina and five flower buds each of $P$. padus and $P$. virginiana were detached from shoots along with 1 to $2 \mathrm{~mm}$ of bark tissue and placed on both sides of a thermoelectric module with 71 thermocouple junctions sandwiched between two conductive plates (Andrews et al., 1983). A thermal conducting paste (Omega Engineering, Stamford, Conn.) was applied to the surface of some plates but it did not improve the LTEs signals compared to the plates without the paste. Moist paper towels were placed on the surface of the plates to induce HTEs but they did not change the HTE temperatures. Buds were held in place with aluminum foil.

Some flower buds were subjected to artificial hardening or dehardening treatments by placing prepared plates in a freezer at $-7 \mathrm{C}$ or in a cold room at $3 \mathrm{C}$ for 2 to 3 days. Plates were transferred to the laboratory in a thermos bottle to prevent thawing of the $-7 \mathrm{C}$ samples during transfer. After preconditioning

Abbreviations: DTA, differential thermal anaylsis; HTEs, high temperature exotherms; LTEs, low temperature exotherms; XVE, xylem vessel elements. 

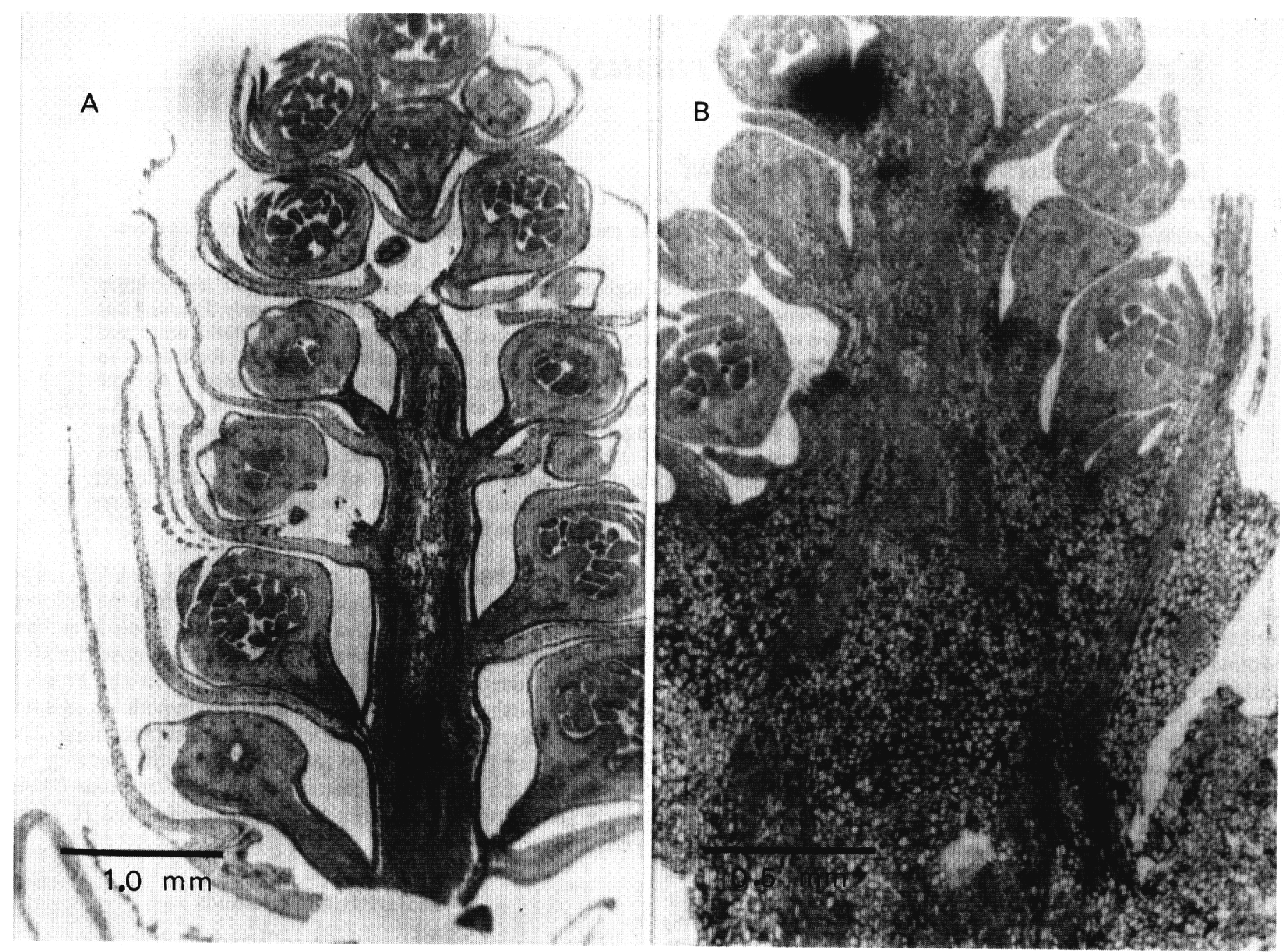

Fig. 1. Longitudinal sections of dormant inflorescence of $(\mathbf{A})$ P. padus $(\times 23.4)$ and $($ B $)$ P. serotina $(\times 50.4)$ sampled during Dec. 1990 .

treatments, plates were suspended in a double-walled, polystyrene box in a freezer. Samples were cooled to $-33 \mathrm{C}$ at a cooling rate of $4 \mathrm{C} / \mathrm{h}$. The $-7 \mathrm{C}$ samples were placed in the $-7 \mathrm{C}$ equilibrated polystyrene box and the $3 \mathrm{C}$ samples were placed in the polystyrene box at $0 \mathrm{C}$.

Freezing was recorded as exothermic events on a multiplechannel strip-chart potentiometer (Linseis L7060, Princeton Junction, N.J.). The temperature within the box was monitored with a 11-mm diameter (36 gauge) copper-constantan thermocouple. Frozen samples were removed from the freezer after it had cooled to $-33 \mathrm{C}$ and, then placed in a $100 \%$ relative humidity (RH) chamber at room temperature (23C) for $24 \mathrm{~h}$ before flower buds were observed for tissue oxidation.

Hydration and dehydration. Twigs of $P$. serotina and $P$. pa$d u s$ with 10 to 15 flower buds were collected and kept in plastic bags on ice until used. For hydration treatments, eight to $10 \mathrm{~cm}$ stem sections with intact buds were vacuum infiltrated at 90.0 $\mathrm{kPa}$ at room temperature for 4 to $6 \mathrm{~h}$. Buds were detached from the twigs and placed on both sides of the thermoelectric module as described. Detached inflorescences without bud scales or bud axis were also placed on plates. Plates were placed in the polystyrene box in the freezer, cooled to $-33 \mathrm{C}$ at a cooling rate of $4 \mathrm{C} / \mathrm{h}$ before being removed, and placed in $100 \% \mathrm{RH}$ at room temperature for $24 \mathrm{~h}$.

Buds and detached inflorescences of $P$. serotina that were used for dehydration tests were collected on the same day. Inflorescences were dried at room temperature to $50 \%, 83 \%$, $87 \%$, and $92 \%$, while buds were air dried to $64 \%$ and $83 \%$ of their original water content before being prepared for the DTA test. The extent of supercooling of the flower bud population was expressed as the temperature at which $50 \%$ (LTE,,) of the intact and detached inflorescences were injured.

Anatomical observation. Twigs of $P$. serotina, $P$. padus, and $P$. virginiana buds were collected at 2 -week intervals during December and weekly during March. Excised flower buds with their scales removed were vacuum infiltrated with formalinacetic acid at $90.9 \mathrm{kPa}$ at room temperature and for 5 to $7 \mathrm{~min}$ and then dehydrated with ethyl-alcohol series. The development of XVE was observed in the bud axis and the raceme of the inflorescence using $15 \mu \mathrm{m}$ serial sections embedded in paraffin and stained with safranin-fast green (Johanson, 1940).

Water movement. Twigs with intact buds of $P$. serotina and $P$. padus were collected with samples for DTA. Twigs were kept in plastic bags on ice, then some were transferred to a room at $3 \mathrm{C}$ and some to a freezer at $-7 \mathrm{C}$ for 2 days before being dissected under a dissecting microscope in the cold room and in a freezer at subfreezing temperatures, respectively. Bud scales and inflorescences were excised. Water content was then determined by drying the samples at $90 \mathrm{C}$ for $24 \mathrm{~h}$ and was expressed as percentage of fresh weight. 

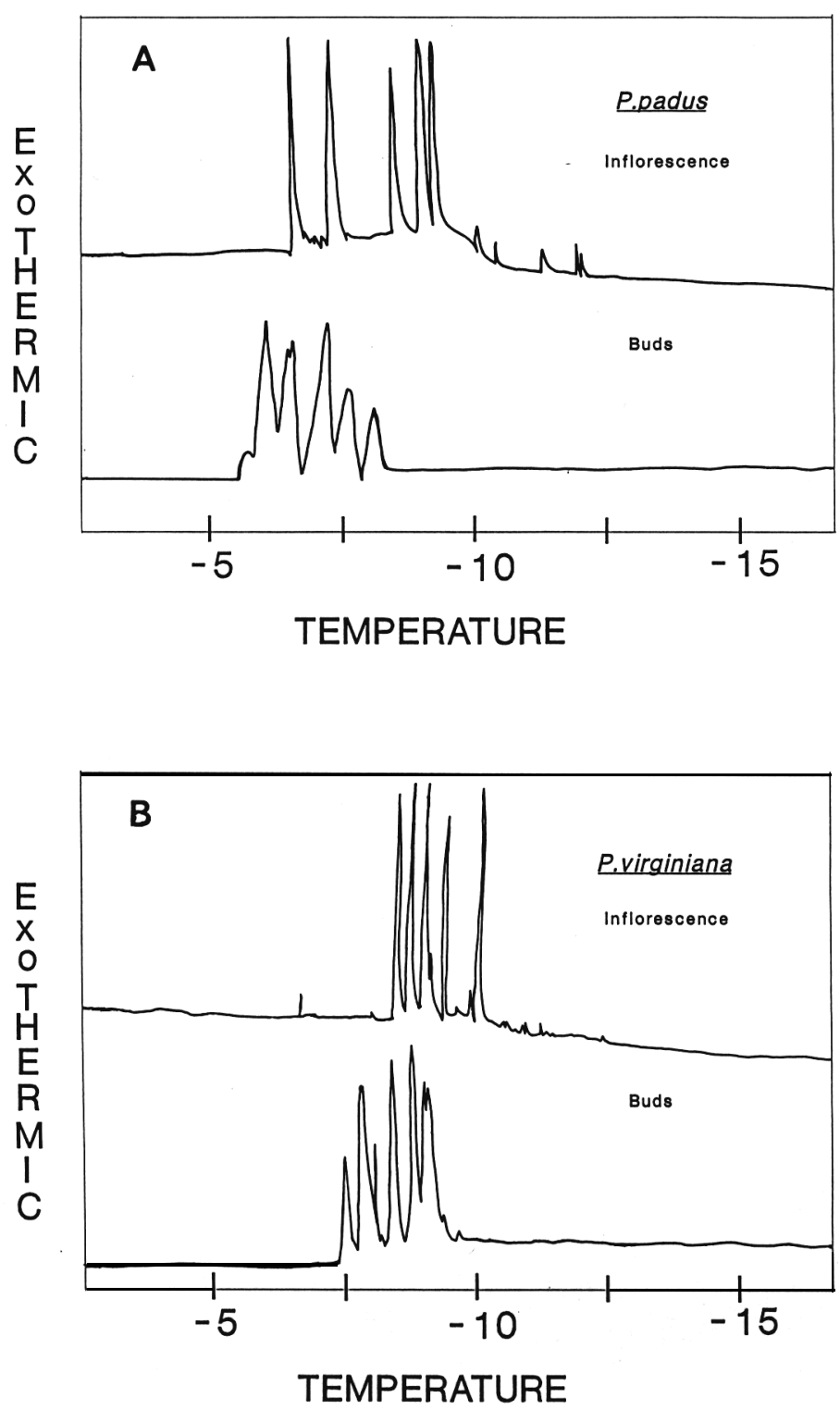

Fig. 2. Typical DTA profile of dormant flower buds and detached inflorescence of (A) $P$. padus and (B) $P$. virginiana sampled $8 \mathrm{Dec}$. 1990 and cooled to $-33 \mathrm{C}$ at $4 \mathrm{C} / \mathrm{h}$. The tracing reflects the freezing of multiple flower buds.

Table 1. The effect of hydration and forcing on viability of $P$. padus flower buds and inflorescence frozen at $4 \mathrm{C} / \mathrm{h}$ to $-33 \mathrm{C}$. Samples collected 17 and 24 Jan. 1991.

\begin{tabular}{lc}
\hline \hline & Buds viable \\
Treatment & $(\%)$ \\
\hline Control & 100 \\
Hydrated bud & 100 \\
Hydrated inflorescence & 89 \\
Forced bud & 0 \\
Forced inflorescence & 0 \\
LSD $P=0.05$ & 5 \\
\hline
\end{tabular}

\section{Results and Discussion}

Exotherm analysis. Species belonging to the subgenus Padus have racemose inflorescences with numerous florets (Fig. 1). Neither flower buds nor the detached inflorescences of $P$. padus and $P$. virginiana deep supercooled during DTA tests (Fig. 2).

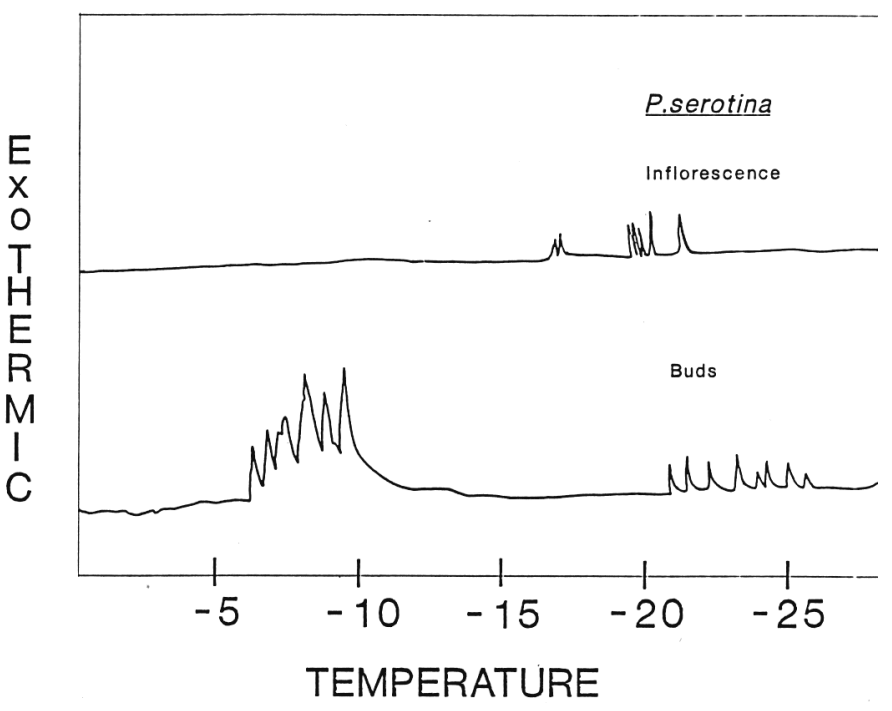

Fig. 3. DTA profile of dormant $P$. serotina flower buds and detached inflorescence sampled 8 Jan. 1991 and cooled to $-33 \mathrm{C}$ at $4 \mathrm{C} / \mathrm{h}$. The tracing reflects the freezing of 10 to 15 flower buds.

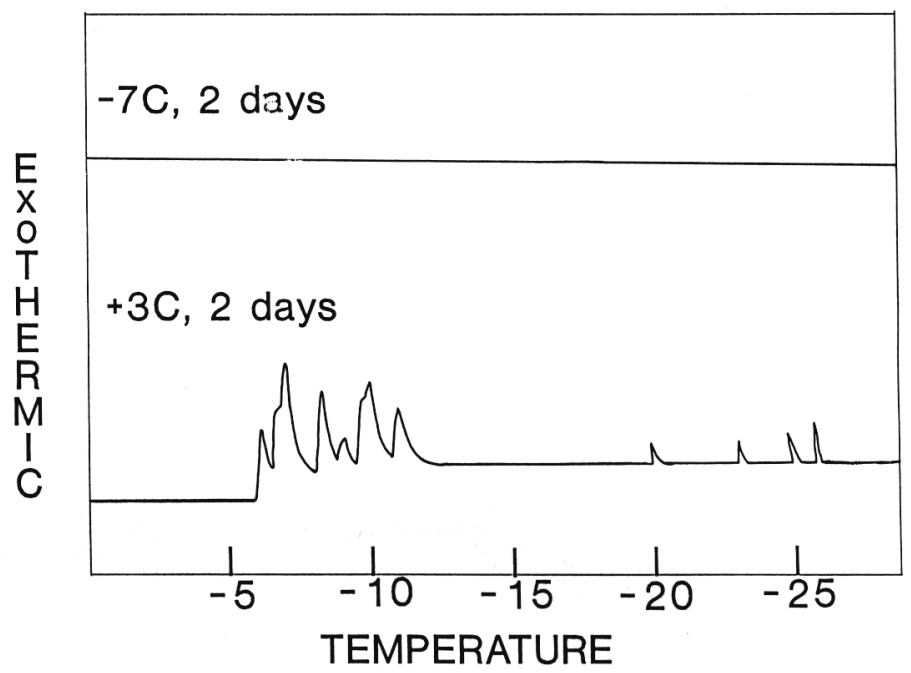

Fig. 4. DTA profile of P. serotina flower buds sampled 10 Jan. 1991 then stored at 3 or $-7 \mathrm{C}$ for 2 days. Buds were cooled to $-33 \mathrm{C}$ at $4 \mathrm{C} / \mathrm{h}$. The tracing reflects the freezing of 10 to 15 flower buds.

Table 2. The effect of hydration and dehydration on the temperature at which $50 \%$ (LTE,,) of the intact flower buds and detached inflorescences of $P$. serotina were injured.

\begin{tabular}{ccc}
\hline \hline \multirow{2}{*}{$\begin{array}{c}\text { Water } \\
\text { content } \\
\text { fresh wt) }\end{array}$} & \multicolumn{2}{c}{ Temperature ("C) } \\
\cline { 2 - 3 } & Bud & Inflorescence \\
\hline 50 & L T E $_{50}$ & -20.4 \\
64 & -- & -- \\
83 & -20.5 & -17.2 \\
87 & -18.5 & -15.4 \\
92 &.-- & -11.6 \\
100 & -- & -9.7 \\
LSD $P=0.05$ & 13.2 & 0.97 \\
\hline
\end{tabular}

Flower buds of $P$. padus (Fig. 2A) produced HTEs between -5.5 and $-8 \mathrm{C}$, while those of $P$. virginiana (Fig. 2B) produced large HTEs at -7.2 to $-9 \mathrm{C}$. In both species, the detached inflorescences freeze at lower temperatures than the intact 


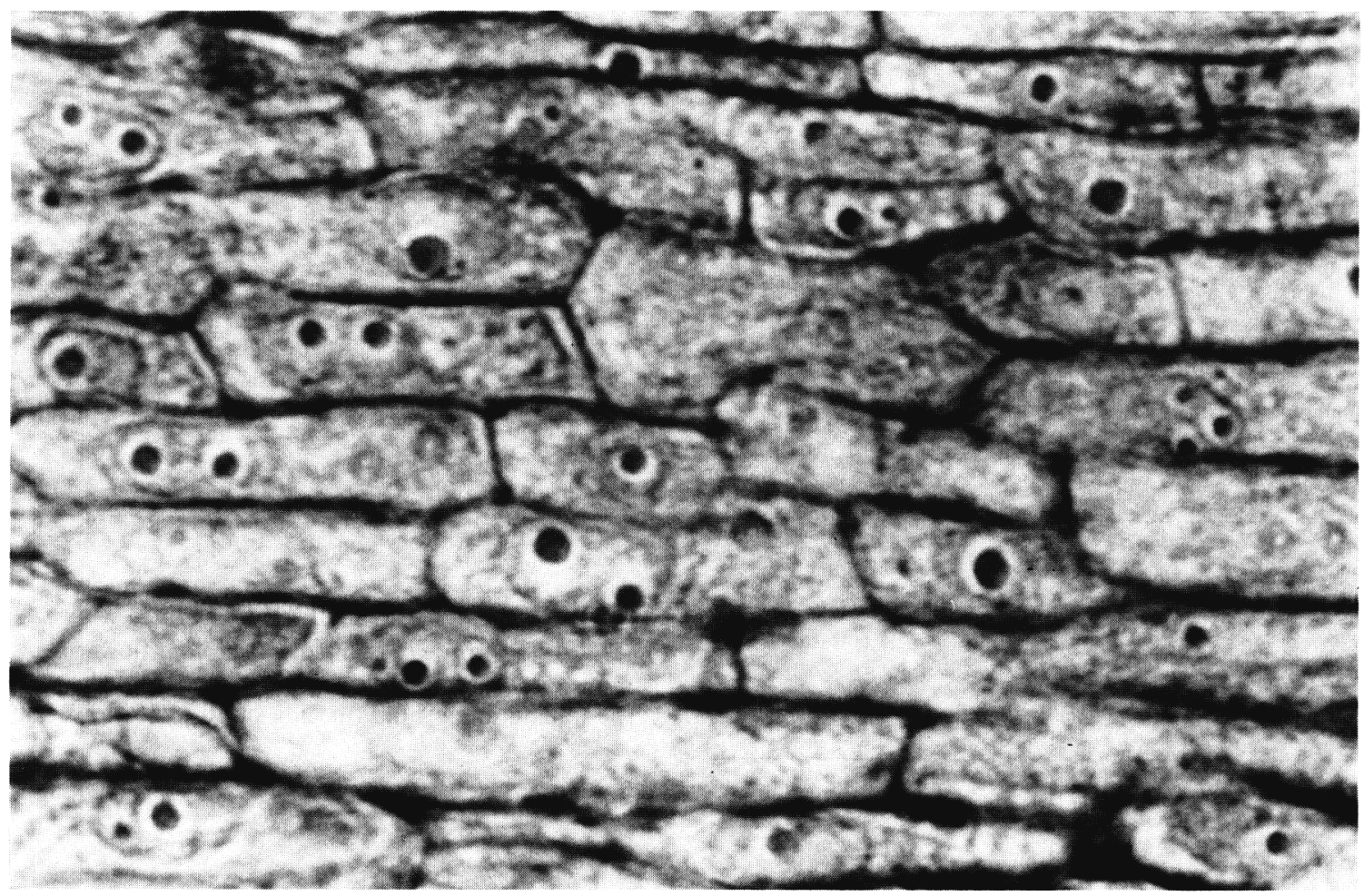

Fig. 5. Longitudinal section of procambium cells within the raceme of dormant P. serotina flower buds sampled mid-December without xylem vessel elements present $(\times 1000)$.

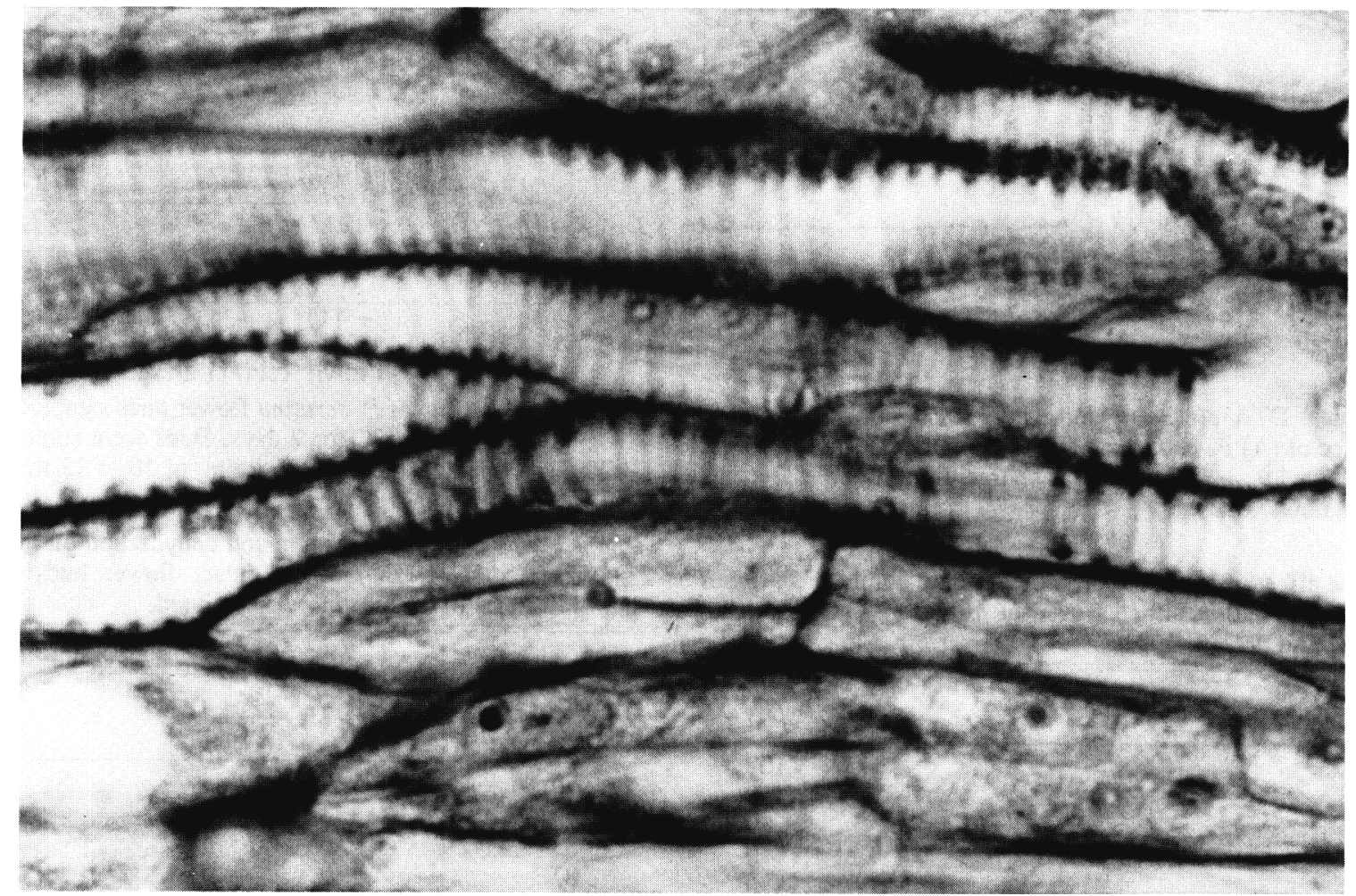

Fig. 6. longitudinal section of xylem vessel elements within the raceme of dormant P. padus flower buds sampled mid-December (x 1000).

ones, indicating that bud scales and the bud axis enhance ice nucleation at higher temperatures. The presence of XVE in the flower bud facilitates the spread of ice formed in the vessels at $-10 \mathrm{C}$ to the supercooled water in the primordium (Ashworth, 1984) and prevents deep supercooling of the primordia. The number of exotherms produced in this study from the freezing of the inflorescences coincided with the number of inflorescence per plate. Exotherms of detached inflorescences occurred as individual peaks, while intact inflorescences produced continuous peaks. Removing bud scales and axis caused an individual inflorescence to freeze at a relatively different temperature.

Both $P$. padus and $P$. virginiana survived $-33 \mathrm{C}$ during dor- 


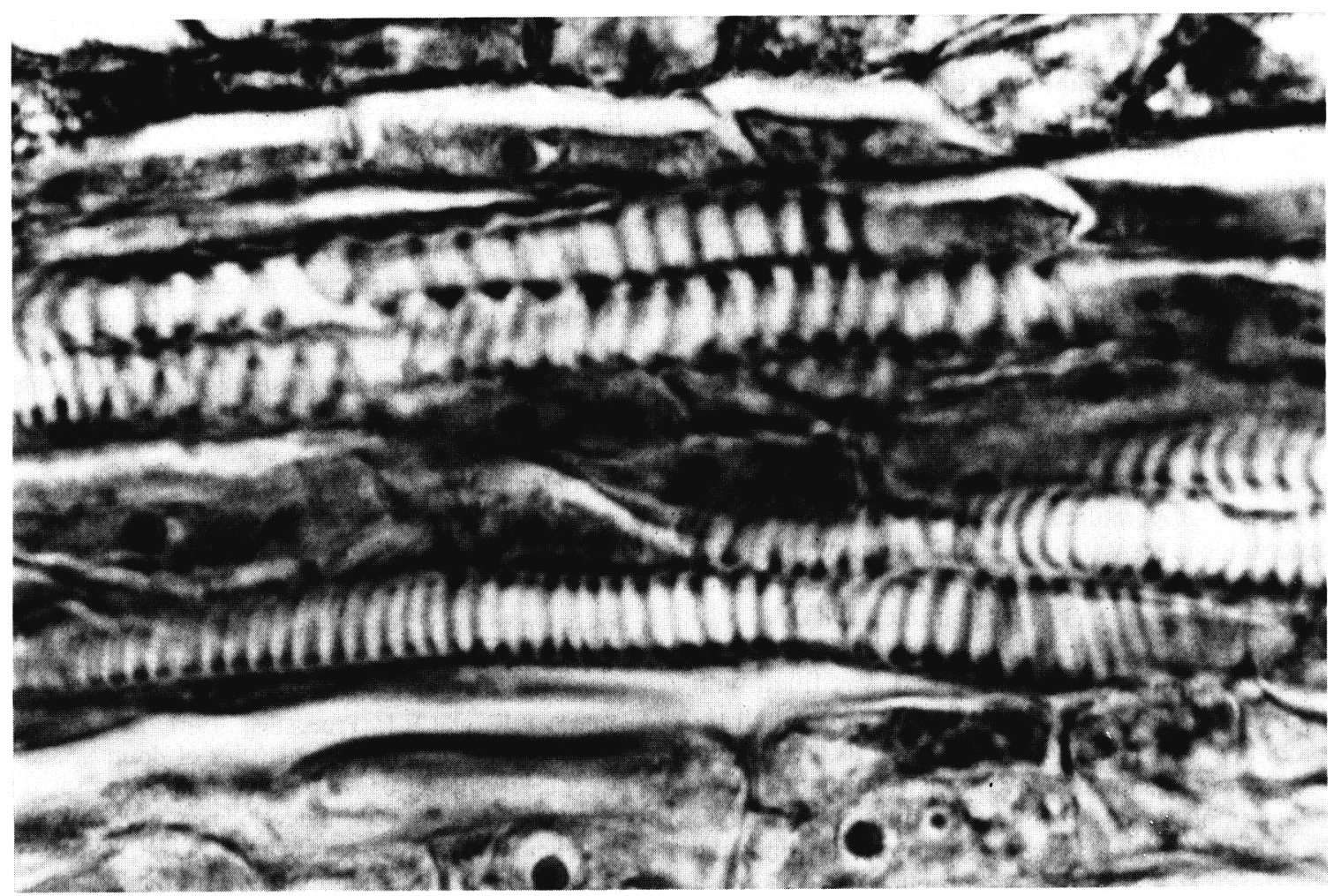

Fig. 7. Longitudinal section of xylem vessel elements within the raceme of developed P. serotina flower buds sampled early March (x 1000).

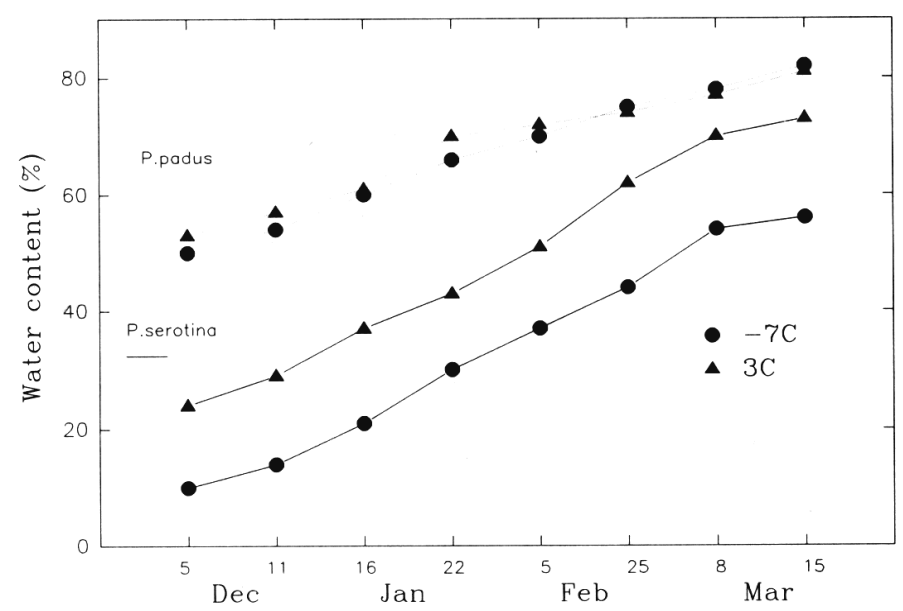

Fig. 8. Water content (percent fresh weight) of the inflorescences of $P$. serotina and $P$. padus stored at 3 or $-7 \mathrm{C}$ for 2 days during Winter and Spring 1990-91.

mancy, as indicated by visual observations. Buds of $P$. padus sampled 24 Jan. and hydrated by vacuum infiltration for $4.5 \mathrm{~h}$ and stored at $100 \% \mathrm{RH}$ for $12 \mathrm{~h}$, survived $-33 \mathrm{C}$ (Table 1). However, buds collected $17 \mathrm{Jan}$. and forced at room temperature (23C) for 7 days did not survive. Apparently, during forcing, flower buds became more sensitive to subfreezing temperatures than dormant, hydrated flower buds. Therefore, an increase in water content of a dormant flower bud alone was insufficient to cause bud deacclimation and injury by subfreezing temperatures.

Rajashekar and Burke (1978) reported that twigs from $P$. serotina produced LTEs, but that the flower bud did not supercool. Our results showed that the freezing behavior of $P$. ser- otina was dissimilar to that of $P$. padus or $P$. virginiana. Dormant flower buds (10 to 15$)$ of the racemose $P$. serotina supercooled like nonracemose Prunus species (Proebsting and Andrews, 1981). The time of sampling and number of buds per test were critical in producing LTEs indicative of supercooling. Not all flower buds per run had developed the ability to supercool, thus using more than one bud was critical in producing LTEs. Most of the LTEs of $P$. serotina were produced only during December and early January. Flower buds and inflorescences of $P$. serotina produced small and sharp LTEs (Fig. 3). Flower bud LTEs occurred between -20 and $-26 \mathrm{C}$, and the detached inflorescences produced LTEs between -17 and -22C. Surprisingly, the number of LTEs of $P$. serotina did not coincide with either the number of flower buds or the inflorescences on the plates. These results suggest that, during dormancy, either not all the inflorescence produced LTEs, the DTA system was not sensitive enough to detect all the LTEs at that time of the season, or simultaneous exotherms occurred.

No LTEs to $-33 \mathrm{C}$ were detected from buds of $P$. serotina frozen for 2 days at $-7 \mathrm{C}$ during dormancy, while those stored at $3 \mathrm{C}$ supercooled and produced LTEs between -20 and $-26 \mathrm{C}$ (Fig. 4). In buds kept at $-7 \mathrm{C}$ for 2 days, water probably migrated from flower primordia to ice crystels between the scales (Quamme, 1978); thus, the primordia either supercooled beyond -33C (our technique could not detect LTEs beyond -33C) or the small amount of water remaining in the inflorescences, when frozen, could not be detected by DTA.

As the season advanced beyond 30 Jan. 1991, LTEs were no longer observed in $P$. serotina flower buds, only detached inflorescences produced LTEs. Therefore, different parts of the bud were studied to determine which part enhanced supercooling of the detached inflorescences. Inflorescences attached to either the bud axis or the scales did not produced LTEs (data not shown). Detached individual florets from the raceme and 
the individual raceme did not supercool either. Thus, dormant inflorescences froze as a unit and not as individual florets.

Hydration and dehydration. Both hydrated and dehydrated flower buds of $P$. serotina produced LTEs (Table 2). Detached inflorescences produced only LTEs, since HTEs are associated with freezing of water in bud scales and bud axis (Graham and Mullin, 1976). Inflorescences dehydrated to 50\% water content produced a $\mathrm{LTE}_{50}$ at -20.4 (Table 2), while hydrated samples produced $\mathrm{LTE}_{50}$ near -9.7 . The LTEs were higher the higher the water content of inflorescences between $64 \%$ to $92 \%$. Intact buds that had been dehydrated to $64 \%$ water content produced LTEs at lower temperatures than buds at $83 \%$ or $100 \%$ water content. These results suggest that dehydration enhanced supercooling of the inflorescence in intact buds and caused a decrease in exotherm temperatures compared to the hydrated samples. This finding agrees with earlier reports on sweet cherry [P. avium (L.) L.] and peach [P. persica (L.) Batsch] flower buds (Andrews and Proebsting, 1987; Quamme, 1983).

Anatomical observations. In dormant $P$. serotina flower buds sampled mid-December, the length of the bud was filled with elongated procambium and small pith cells with very small intercellular spaces (Fig. 5). XVEs were restricted to the base of the flower bud axis (not shown). In contrast, dormant flower buds of $P$. padus sampled mid-December had differentiated XVE in the raceme (Fig. 6), which presumably prevented both the buds and the inflorescences from supercooling. XVE played a major role in regulating the freezing behavior of $P$. padus and $P$. virginiana. XVEs of $P$. serotina started to develop and grow into the inflorescence during early March when buds developed into the first swelling stage (Fig. 7). These observations do not agree with an earlier report that dormant $P$. serotina flower buds had XVEs developed in the inflorescence (Ashworth, 1984). Our observations would explain the seasonal differences in supercooling observed in this study.

Water movement. Frozen inflorescences of $P$. serotina had lower water content than $P$. padus and dehydrated more during storage at $-7 \mathrm{C}$ than at $3 \mathrm{C}$ (Fig. 8). No obvious changes in water content for $P$. padus inflorescences were observed during storage at 3 or $-7 \mathrm{C}$. This result suggests that water in $P$. serotina flower buds migrated out from the inflorescence during storage at $-7 \mathrm{C}$ to freeze around and in the scales and bud axis, thus decreasing water content of the inflorescences. In contrast, water in frozen buds of $P$. padus did not migrate during 2 days of storage at $-7 \mathrm{C}$; therefore, no significant decrease in water content of the inflorescences was observed. Apparently P. serotina bud scales and axes serve as an ice sink, as they do in Prunus species having nonracemose inflorescences (Quamme, 1978), unlike in $P$. padus and $P$. virginiana. Inflorescences of $P$. serotina air dried for $40 \mathrm{~min}$ at room temperature lost $50 \%$ of their water content; while only $12 \%$ and $17 \%$ was lost from $P$. padus and $P$. virginiana, respectively.

In summary, XVE is the main factor that prevented supercooling in $P$. padus and $P$. virginiana. However, flower buds of $P$. serotina did not develop XVE in the inflorescences until early March, yet supercooling was prevented earlier; therefore, a factor other than XVE prevented supercooling of the intact inflorescences. The detached inflorescences of $P$. serotina supercooled beyond 30 Jan. 1991. Supercooling was enhanced by dehydration, and buds kept at $-7 \mathrm{C}$ for 2 days either supercooled beyond $-33 \mathrm{C}$ or the small amount of water that froze was not detected by the DTA technique. Not all flower buds supercooled during dormancy or the LTEs were not big enough to be detected by DTA, thus using more than one flower bud is essential to record LTEs.

\section{Literature Cited}

Andrews, P.K., E.L. Proebsting, and G.S. Campbell. 1983. An exotherm sensor for measuring the cold hardiness of deep-supercooled. flower buds by differential thermal analysis. HortScience 18:77-78.

Andrews, P.K. and E.L. Proebsting. 1987. Effect of temperature on the deep supercooling characteristics of dormant and deacclimated sweet cherry flower buds. J. Amer. Soc. Hort. Sci. 108:755-759.

Ashworth, E.N. 1984. Xylem development in Prunus flower buds and the relationship to deep supercooling. Plant Physiol. 74:862-865.

Burke, M.J. and C. Stushnoff. 1979. Frost hardiness: A discussion of the possible molecular causes of injury with particular reference to deep supercooling of water, p. 197-225. In: H. Mussel1 and R.C. Staples (eds.). Stress physiology in crop plants. Wiley, New York.

Graham, P.R. and R. Mullin. 1976. The determination of lethal freezing temperatures in buds and stems of deciduous azalea by a freezing curve method. J. Amer. Soc. Hort. Sci. 101:3-7.

Johanson, D.A. 1940. Plant microtechnique. McGraw Hill, New York. Proebsting, E.L. and P.K. Andrews. 1981. Supercooling and Prunus flower bud hardiness, p. 529-539. In: P.H. Li and A. Sakai (eds.). Plant cold hardiness and freezing stress. vol. II. Academic Press, New York.

Quamme, H.A. 1974. An exothermic process involved in the freezing injury to flower buds of several Prunus species. J. Amer. Soc. Hort. Sci. 99:315-318

Quamme, H.A. 1978. Mechanism of supercooling in overwintering peach flower buds. J. Amer. Soc. Hort. Sci. 103:57-61.

Quamme, H.A. 1983. Relationship of air temperature to water content and supercooling of over-wintering peach flower buds. J. Amer. Soc. Hort. Sci. 108:697-701.

Rajashekar, C. and M.J. Burke. 1978. The occurrence of deep undercooling in the genera Pyrus, Prunus and Rosa, p. 213-225. In: P.H. $\mathrm{Li}$ and A. Sakai (eds.). Plant cold hardiness and freezing stress. vol. I. Academic, New York.

Rehder, A. 1950. Manual of cultivated trees and shrubs. MacMillan, New York. 